\title{
Evaluation of five pearl millet varieties for yield and forage quality under two planting densities in the Sahel
}

\author{
Dov Pasternak ${ }^{1}$, Ali Ibrahim ${ }^{2 \star}$ and Ayantunde Augustine ${ }^{3}$ \\ ${ }^{1}$ International Adviser Drylands Agriculture, 16/12 Harav Goren St. Rishon Letzion 75753, Israel. \\ ${ }^{2}$ International Crops Research Institute for the Semi-Arid Tropics (ICRISAT), P. O. Box 12404, Niamey, Niger. \\ ${ }^{3}$ International Livestock Research Institute (ILRI), Bamako, Mali.
}

Accepted 21 May, 2012

\begin{abstract}
In the Sahel that is typified by an agro-pastoral system and a long dry season between rains, the availability of animal feed is a very serious constraint. The objectives of this study were to identify pearl millet varieties with high forage productivity under rainfed conditions in the Sahel; to identify best planting densities and to find physiological mechanisms conducive to high forage productivity in pearl millet. The experiment was carried out at the ICRISAT Sadore Research Center in Niger during the 2006 rainy season. Five long duration varieties (Malgorou, Batchoudine, Sanioba, Yabo Maiwa and Somno Damari) as forage crops were compared at two planting densities $(10,000$ and $20,000 \mathrm{hills} / \mathrm{ha})$. Dry matter yield and forage quality was assessed at the boot, anthesis and at the soft dough stages. The higher planting density gave in this year higher dry matter (and grain) yield than the lower density. The dough stage was the most suitable stage for harvest because dry matter was at its highest. However, organic matter digestibility and crude protein are higher at the boot stage compared with the dough stage. The Malgorou variety gave the highest dry matter yield at the dough stage $(8.57$ tons/ha at the high planting density). The high forage productivity of this variety was attributed to the longer growing period of time before anthesis and the bigger number of tillers. The results of this study demonstrated that long duration varieties of pearl millet can become an important source of forage in the Sahel under rainfed conditions.
\end{abstract}

Key words: Forage millet, varieties, planting density, harvest stage, dry matter yield, Sahel.

\section{INTRODUCTION}

Feed scarcity is the major constraint for livestock production in the Sahel (Glatzle, 1992). In this region, animals graze in natural rangelands for about 6 months of the year and live from crop residues for the remaining six months (Williams et al., 1997). Animal fattening is an important economic practice in the Sahel. Fattening of sheep before the Islamic festival Eid al Kabir (commonly known as Tabaski) is mostly conducted by resource poor farmers (Hiernaux and Ayatunde, 2004). Resource rich entrepreneurs carry out mainly cattle fattening for local market and for regional exports. In the towns and cities of the Sahel, many households raise livestock in their backyards. These animals are fed from purchased

*Corresponding author. E-mail: i.ali@icrisatne.ne. Tel: +227 96 2673 74. Fax: + 22720734329. fodder. Forage trade is one of the most important economic activities in many Sahelian cities. The main sources of rough fodder in the Sahel are: bush straw, sorghum straw, groundnut haulms and cowpeas hay. Pearl millet (Pennisetum glaucum [L.] R. Br.) is the main grain crop of the Sahel. This species is tolerant to drought, heat and to the nutrients-leached acid sandy soils of this region (Andrew and Kumar, 1992). Potentially, pearl millet has one of the highest rates of growth among the tropical cereals (Craufurd and Bidinger, 1989). In trials in Alabama, dry matter yield of rain-fed pearl millet was around $7.0 \mathrm{t} / \mathrm{ha}$, significantly higher than that of Sudax, a common high yielding forage crop in Southern USA. Pearl millet fodder is comparable in quality or even superior to fodder from other grasses. For example, De Leeuw and Schihorn (1978) demonstrated that heifers grazing pearl millet gained more weight than heifers grazing Rhodes grass (Chloris gayana). Likewise, 
Stobbs (1975) found that feeding forage millet to milking cows resulted in higher milk yield as compared with feeding forage sorghum (Sorghum bicolor).

The high growth rate of pearl millet combined with its high adaptability to the Sahelian climate and soils makes it a most promising candidate of rain-fed forage in the Sahel. Forage millet is commonly grown in many countries of the world but not in West Africa where grain varieties dominate the landscape (Andrew and Kumar, 1992) because local farmers put higher emphasis on grain than on forage production. For this reason very little research has been conducted on millet forage production in the Sudano Sahel under rainfed conditions. Makeri and Ugherughe (1992) is an exemption. These workers compared the productivity and some quality parameters of 20 pearl millet varieties in northern Nigeria. Dry matter production ranged between 7.2 to 9.92 tons $\mathrm{ha}^{-1}$, but there were no differences in crude protein content among the 20 varieties. Since so little has been done on rainfed forage millet in the Sahel there was a need to identify best sowing density and best harvest time for maximum forage yield under rainfed conditions. Alhassan and Nwasike (1987) working in northern Nigeria found that forage yield was highest at seed set as compared with earlier stages but this was inversely related to forage quality. According to literature the important traits of forage millet varieties are:

1. Dwarfness: Dwarf varieties of pearl millet should make better quality forage than tall varieties because the dwarf varieties have a higher leaf/stem ratio (Johnson et al., 1968). However total biomass production is lower.

2. Long duration: Burton et al. (1986) demonstrated that late maturing varieties of millet produce higher dry matter yield and are leafier than early maturing varieties. Late maturing varieties contain higher crude protein concentration and are more digestible than early varieties.

3. Regeneration following harvests: Most forage millet varieties are harvested a few times during the season. Burger and Hittle (1967) found that highest yields are achieved with three harvests per growing season. However in our preliminary studies, multiple cuttings actually reduced dry matter yield (unpublished).

The above analysis led to the design of an experiment aiming at the: (i) identification of pearl millet varieties, planting densities and best harvest timing to give maximum forage production at reasonable feed quality and (ii) identification of physiological traits responsible for high forage yield in pearl millet.

\section{MATERIALS AND METHODS}

\section{Study site}

The experiment was conducted at the Sadoré Research Station of ICRISAT in Niger. Sadoré is situated at latitude $13^{\circ} 15^{\prime} \mathrm{N}$ and longitude $2^{\circ} 18^{\prime} \mathrm{E}, 40 \mathrm{~km}$ southeast from Niamey, the capital of Niger. The climate is characterized by a rainy season that occurs between June and September, and a dry season that prevail during the rest of the year. The mean annual rainfall at Sadoré is $560 \mathrm{~mm}$ (Sivakumar, 1987). The average temperature is $29^{\circ} \mathrm{C}$ (West et al., 1984). The soil is classified as a sandy silicious isohyperthemic Psammentic Paleustalf. It belongs to the Labucheri type, characterized by a high sand content, low native fertility with low organic matter and low cation exchange capacity that limits nutrient storage and water holding ability. These soils are generally very strongly acidic to strongly acidic (pH 4.5 - 5.0), with aluminum comprising of a high percentage (47\%) of the exchangeable cations (West et al., 1984).

\section{Experimental layout and determinations}

The experiment was set up in a split plot design with five replications included two factors. Pearl millet varieties (Malgorou, coming from the Dosso region of Niger, Batchoudine and Saniobo originating in the Aïr Mountains-Niger, Yabo Maiwa from central Mali and Somno Damari coming from a village at the vicinity of the ICRISAT experimental station) were arranged in the main plots and two planting densities $1 \mathrm{~m} \times 1 \mathrm{~m}(10,000$ hills/ha) and $1 \mathrm{~m} \times 0.5 \mathrm{~m}$ $(20,000$ hills/ha) were assigned in the subplots. Main plot size was $18 \mathrm{~m} \times 18 \mathrm{~m}\left(324 \mathrm{~m}^{2}\right)$ and the sub plot size was $18 \mathrm{~m} \times 8 \mathrm{~m}(144$ $\mathrm{m}^{2}$ ). The area of the experimental field was $1,336 \mathrm{~m}^{2}$. The experiment was planted in a field that lay fallow during a period of 5 years prior to sowing. A complete fertilizer (15-15-15) containing $15 \% \mathrm{~N}, 6.5 \% \mathrm{P}$ and $12.4 \% \mathrm{~K}$ was broadcasted prior to planting at a rate of $150 \mathrm{~kg} / \mathrm{ha}$ and incorporated with a disc.

Millet was sown in hills on July 14th, 2006. Two weeks after planting, plants were thinned and 2 plants per hill were left till harvest. There were two weeding events. The plants were harvesting at three events: $50 \%$ boot stage, $50 \%$ anthesis and at $50 \%$ dough stage. Time for $50 \%$ boot, $50 \%$ anthesis and $50 \%$ dough stage was determined for each variety. The number of tillers per plant was counted on the third harvest occasion. In each of the three harvest occasions 45 hills/plot were harvested at the high density treatment and 24 hills/plot were harvested at the low density treatment. Plants were separated into leaves, stems and heads and fresh weight was determined.

Plant parts were dried for 48 hours in a forced ventilation oven at $70^{\circ} \mathrm{C}$ and dry weight was determined. In addition to the three main harvest events plants were sampled every ten days from germination until the wax stage for leaf area and dry weight determinations. Samples were taken only from the low density treatment. Six hills per plot were harvested. Leaf area was determined using a L1 3100 Area meter. Plants were dried and dry weight was also determined. These data were used to calculate the leaf area index ( $\mathrm{LAl})$ and the relative growth rates (RGR) of the five varieties (Hunt, 1990).

\section{Forage quality analysis}

Composite samples were taken from sampled plant parts at each harvest event and were analyzed for feed value. Neutral detergent fiber (NDF) and acid detergent fiber (ADF) and lignin were analyzed according the procedures of Van Soest et al. (1985). Cellulose was calculated as the differences of ADF - lignin. Organic matter digestibility (OMD) was determined by the in vitro gas production technique calibrated with standards obtained in vivo (Menke et al., 1979). Nitrogen was determined with the Kjeldahl method (Bremner and Mulvaney, 1982) and crude protein content was determined by multiplying the $\mathrm{N}$ content by 6.25 . 


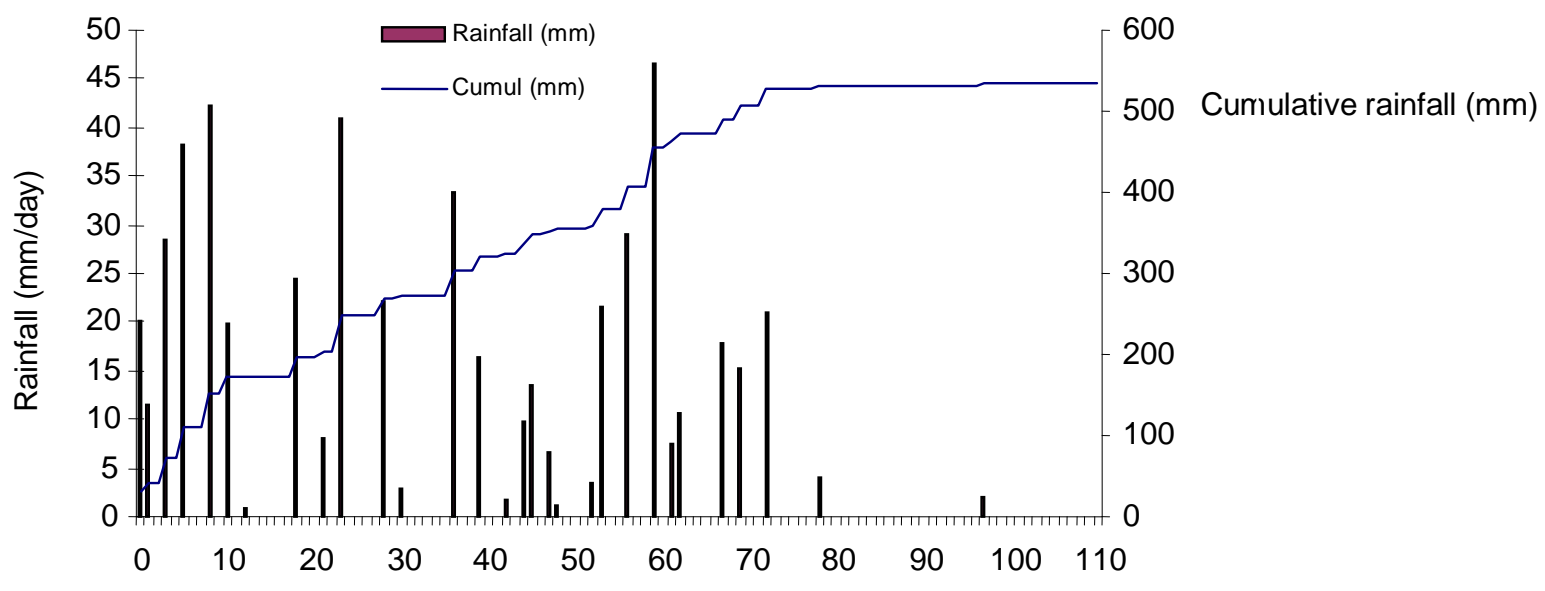

Day after sowing (DAS)

Figure 1. Rainfall distribution (mm) during 2006 rainy season at ICRISAT-Sahelian Center, Sadoré Niger.

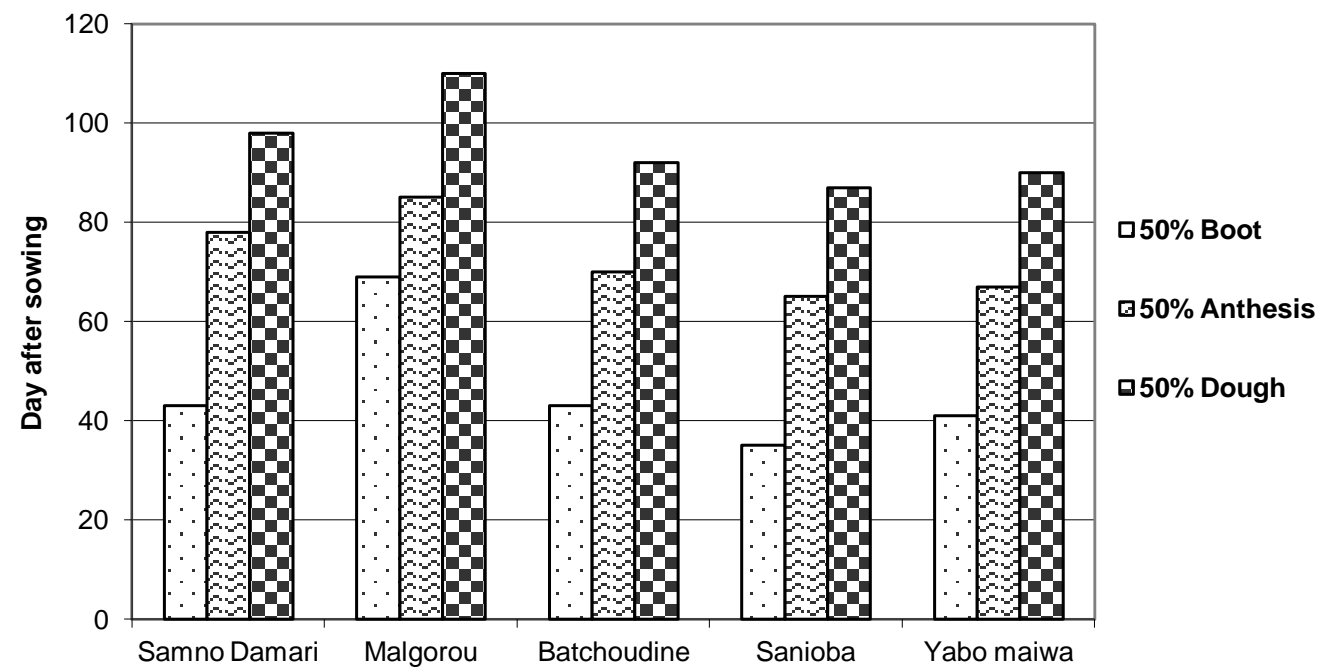

Figure 2. Number of days for $50 \%$ boot, flowering and dough stages for the five varieties.

\section{Statistical analysis}

Data collected were subjected to analysis of variance using the GenStat $\circledast 9^{\text {th }}$ (Lawes Agricultural Trust, 2007). Least significant difference at $5 \%$ level of significance was used for means separation.

\section{RESULTS AND DISCUSSION}

\section{Rainfall distribution}

The total rain recorded in 2006 was similar to the average for the region with a very good distribution during the period July to October (Figure 1). This factor together with the long fallow period that proceeded planting were probably responsible for the high dry matter and grain yield obtained in this year. This good rainfall distribution increased soil moisture content which increased the solubility and availability of soil nutrients, all of which in turn increased nutrient absorption, thereby resulting in high dry matter production.

\section{Phenological stages}

The number of days for boot, anthesis and dough stages for the five varieties is given in Figure 2. The variety Malgorou reached the boot stage 20 days, anthesis 15 days and dough stages 15 days later than then of the other four varieties. 


\section{Growth parameters}

The number of tillers per plant for the five varieties at the two planting densities at the dough stage is given in Table 2. There were no significant differences in the number of tillers/plant between planting density treatments. However, varieties had significant effect on number of tillers per plant $(P<0.05)$. The varieties Malgorou and Batchoudine had significantly higher number of tillers as compared with the other three varieties.

The leaf area index of the five varieties (low density only) during the first 91 days after sowing is given in Figure 3. The analysis of variance showed significant difference between the varieties $(P<0.05)$ as indicated in Figure 3. While LAI of the other four varieties peaked at 71 days after sowing, the LAl of Malgorou continued to increase for an additional 10 days resulting in a significantly higher LAI for this variety during days 80-100 after sowing. Moreover, the relative growth rate (Figure 4) was similar for all 5 varieties during the first three months after sowing, indicating that there were no differences in the potential productivity among the five varieties $(P<0.05)$.

\section{Dry matter production}

Effect of varieties and planting densities as well as their interactions at three growth phases on total dry matter production is given in Table 1. Dry matter yield was significantly affected by varietal differences $(P<0.05)$. The Malgorou variety produced at both the anthesis and dough stages significantly higher dry matter than the other four varieties. A dry matter yield of 8.57 tons/ha obtained by the Malgorou variety at the dough stage was higher than recorded yields of rain fed forage millet with multiple cuttings (Craufurd and Bidinger 1989) and similar to forage yields obtained under high fertilization regimes (Reddy et al., 2003). It is comparable to dry matter yield from four cuttings in a higher rainfall area in north Nigeria (Makeri and Ugherughe (1992). Analysis of variance showed that planting densities had significantly affected dry matter yield $(\mathrm{P}<0.05)$.

The mean separation presented in Table 2 showed that the dense $(0.5 \times 1.0 \mathrm{~m})$ planting spacing gave significantly higher dry matter yield than the sparse $(1 \mathrm{~m} \times 1 \mathrm{~m})$ sowing at all three growth stages. Rajala (2006) demonstrated that high density $(20,000$ hills/ha $)$ sowing is advantageous only under good rain distribution (short dry spells) as was evidenced in the 2006 rainy season (Figure 1). The increment of dry matter yield with high planting density was due to the high number of plant $/ \mathrm{m}^{2}$ which compensates the lowest number of tiller/ plant recorded with high planting density. Similar finding was recorded by Ali (2010). On the other hand, the interaction of varieties and planting densities had no significant effect on dry matter yield $(P>0.05)$.
Leaf /stem ratio for the five varieties at three growth stages is given in Table 1. Leaf/stem ratio was significantly affected by cutting stages $(P<0.05)$. In general and as expected, the leaf/stem ratio was highest during boot but with no statistical differences between varieties and planting densities. At anthesis, the leaf/stem ratio was about half the ratio at boot. The leaf/stem ratio for the varieties Sanioba and Somno Damari increased at the dough stage as compared with anthesis.

\section{Grain yields}

The data presented in Table 3 showed that grain yields were significantly affected by the varietal differences and planting densities $(P<0.05)$. Highest grain yield was obtained with Somno Damari (2.19 tons/ha) at the high sowing density treatment. Malgorou had the lowest grain yield but the highest total dry matter yield compared to the others varieties. Apparently, this variety 'invests' more dry matter into the shoot than into grains, which makes it a good candidate for dual purpose (grains and forage) millet. Means separation showed that with the increase in plant density, grain yields increase significantly (Table 4). This increment of grain with high plant density can be related to high number of plant $/ \mathrm{m}^{2}$. Similar finding was reported by Al-Suhaibani (2011).

\section{Forage quality}

Effect of varieties and planting densities presented in Table 5 showed that except cellulose content, all parameters of forage quality observed in this study (crude protein, in vitro digestibility and lignin contents) were significantly affected by the varietal differences. Planting densities had no statistical differences on in vitro digestibility, lignin and cellulose contents. However, planting densities had significantly affected crude protein content $(P<0.05)$. Protein content at boot stage was the highest, diminishing with plant age (Table 6). At both the boot and at the anthesis stages, the low planting density plants had higher protein content than the high-density forage.

Furthermore, the means separation presented in Table 6 showed that crude protein of Malgorou was significantly lower than that of other varieties where the highest crude protein content was obtained with Samno Damari variety. The ODMD of the millet forage is similar to that of quality sorghum stover (Agyemang et al., 1998). Also, the highest in vitro digestibility occurred during the boot stage and the lowest during anthesis. At the dough stage, the Malgorou variety had the highest ODMD (600 g. $\left.\mathrm{kg}^{-1}\right)$ of all five varieties. Lignin content of the five varieties was highest at anthesis, where it ranged between 9.3 to $12.1 \%$ compared to others cutting stages. 
Table 1. Total dry matter $(\mathrm{kg} / \mathrm{ha})$ and leaf/stem ratio of five pearl millet varieties planted at two planting densities harvested at three developmental stages.

\begin{tabular}{|c|c|c|c|c|}
\hline Cutting stage & Variety & Planting density & Total dry matter (kg/ha) & Leaf/stem ratio $(\mathrm{kg} / \mathrm{kg})$ \\
\hline \multirow{10}{*}{ Boot } & \multirow{2}{*}{ Batchoudine } & $1 \mathrm{~m} \times 0.5 \mathrm{~m}$ & 1,388 & 0.68 \\
\hline & & $1 \mathrm{~m} \times 1 \mathrm{~m}$ & 1,124 & 0.65 \\
\hline & \multirow{2}{*}{ Malgorou } & $1 \mathrm{~m} \times 0.5 \mathrm{~m}$ & 2,462 & 0.81 \\
\hline & & $1 \mathrm{~m} \times 1 \mathrm{~m}$ & 1,614 & 0.92 \\
\hline & \multirow{2}{*}{ Sanioba } & $1 \mathrm{~m} \times 0.5 \mathrm{~m}$ & 2,044 & 0.82 \\
\hline & & $1 \mathrm{~m} \times 1 \mathrm{~m}$ & 1,401 & 0.86 \\
\hline & \multirow{2}{*}{ Somno Damari } & $1 \mathrm{~m} \times 0.5 \mathrm{~m}$ & 1,715 & 0.92 \\
\hline & & $1 \mathrm{~m} \times 1 \mathrm{~m}$ & 1,275 & 0.75 \\
\hline & \multirow{2}{*}{ Yabo Maiwa } & $1 \mathrm{~m} \times 0.5 \mathrm{~m}$ & 1,464 & 0.54 \\
\hline & & $1 \mathrm{~m} \times 1 \mathrm{~m}$ & 1,299 & 0.61 \\
\hline \multirow{10}{*}{ Anthesis } & \multirow{2}{*}{ Batchoudine } & $1 \mathrm{~m} \times 0.5 \mathrm{~m}$ & 5,000 & 0.48 \\
\hline & & $1 \mathrm{~m} \times 1 \mathrm{~m}$ & 4,260 & 0.35 \\
\hline & \multirow{2}{*}{ Malgorou } & $1 \mathrm{~m} \times 0.5 \mathrm{~m}$ & 6,640 & 0.38 \\
\hline & & $1 \mathrm{~m} \times 1 \mathrm{~m}$ & 7,100 & 0.34 \\
\hline & \multirow{2}{*}{ Sanioba } & $1 \mathrm{~m} \times 0.5 \mathrm{~m}$ & 5,830 & 0.34 \\
\hline & & $1 \mathrm{~m} \times 1 \mathrm{~m}$ & 4,440 & 0.42 \\
\hline & \multirow{2}{*}{ Somno Damari } & $1 \mathrm{~m} \times 0.5 \mathrm{~m}$ & 5,360 & 0.41 \\
\hline & & $1 \mathrm{~m} \times 1 \mathrm{~m}$ & 3,150 & 0.46 \\
\hline & \multirow{2}{*}{ Yabo Maiwa } & $1 \mathrm{~m} \times 0.5 \mathrm{~m}$ & 5,210 & 0.41 \\
\hline & & $1 \mathrm{~m} \times 1 \mathrm{~m}$ & 4,220 & 0.40 \\
\hline \multirow{10}{*}{ Dough } & \multirow{2}{*}{ Batchoudine } & $1 \mathrm{~m} \times 0.5 \mathrm{~m}$ & 6,627 & 0.45 \\
\hline & & $1 \mathrm{~m} \times 1 \mathrm{~m}$ & 5,038 & 0.50 \\
\hline & \multirow{2}{*}{ Malgorou } & $1 \mathrm{~m} \times 0.5 \mathrm{~m}$ & 8,574 & 0.38 \\
\hline & & $1 \mathrm{~m} \times 1 \mathrm{~m}$ & 6,277 & 0.49 \\
\hline & \multirow{2}{*}{ Sanioba } & $1 \mathrm{~m} \times 0.5 \mathrm{~m}$ & 6,068 & 0.55 \\
\hline & & $1 \mathrm{~m} \times 1 \mathrm{~m}$ & 4,777 & 0.59 \\
\hline & \multirow{2}{*}{ Somno Damari } & $1 \mathrm{~m} \times 0.5 \mathrm{~m}$ & 5,036 & 0.60 \\
\hline & & $1 \mathrm{~m} \times 1 \mathrm{~m}$ & 3,219 & 0.92 \\
\hline & \multirow[t]{2}{*}{ Yabo Maiwa } & $1 \mathrm{~m} \times 0.5 \mathrm{~m}$ & 6,776 & 0.44 \\
\hline & & $1 \mathrm{~m} \times 1 \mathrm{~m}$ & 4,054 & 0.51 \\
\hline \multicolumn{5}{|l|}{ Probabilty $(0.05)$} \\
\hline Varieties(V) & & & $<0.001$ & 0.256 \\
\hline Plant densities (PD) & & & $<0.001$ & 0.240 \\
\hline Cutting stages(CS) & & & $<0.001$ & $<0.001$ \\
\hline$V \times P D$ & & & 0.380 & 0.284 \\
\hline $\mathrm{V} \times \mathrm{CS}$ & & & $<0.001$ & 0.027 \\
\hline$P D \times C S$ & & & $<0.001$ & 0.264 \\
\hline$V \times P D \times C S$ & & & 0.016 & 0.144 \\
\hline
\end{tabular}


Table 2. Means separation on total dry matter $(\mathrm{kg} / \mathrm{ha})$, leaf/stem ratio and Number of tillers/hill of five pearl millet varieties planted at different densities.

\begin{tabular}{|c|c|c|c|c|}
\hline Data & Treatment & Total dry matter (kg/ha) & Leaf/stem ratio (kg/ha) & Number of tillers/hil \\
\hline \multirow{5}{*}{ Means of varieties } & Batchoudine & $3,907^{b}$ & $0.52^{\mathrm{a}}$ & $11.0^{\mathrm{a}}$ \\
\hline & Malgorou & $5,444^{\mathrm{a}}$ & $0.55^{\mathrm{a}}$ & $12.5^{\mathrm{a}}$ \\
\hline & Sanioba & $4,093^{b}$ & $0.60^{\mathrm{a}}$ & $7.8^{\mathrm{c}}$ \\
\hline & Somno Damari & $3,293^{c}$ & $0.68^{\mathrm{a}}$ & $9.6^{b}$ \\
\hline & Yabo Maiwa & $3,838^{b}$ & $0.48^{\mathrm{a}}$ & $9.9^{b}$ \\
\hline \multirow{2}{*}{ Means of plant densities } & $1 \mathrm{~m} \times 0.5 \mathrm{~m}$ & $4,680^{\mathrm{a}}$ & $0.58^{\mathrm{a}}$ & $9.7^{\mathrm{a}}$ \\
\hline & $1 \mathrm{~m} \times 1 \mathrm{~m}$ & $3,550^{b}$ & $0.65^{\mathrm{a}}$ & $10.6^{\mathrm{a}}$ \\
\hline \multirow{3}{*}{ Means of cutting stage } & Boot & $1,579^{\mathrm{C}}$ & $0.88^{a}$ & \\
\hline & Anthesis & $5,122^{b}$ & $0.42^{c}$ & \\
\hline & Dough & $5,645^{\mathrm{a}}$ & $0.58^{\mathrm{b}}$ & \\
\hline \multicolumn{5}{|l|}{ LSD for: } \\
\hline Varieties & & 579.4 & 0.23 & 1.74 \\
\hline Planting densities & & 234.5 & 0.12 & 1.30 \\
\hline Cutting stages & & 299.0 & 0.15 & \\
\hline
\end{tabular}

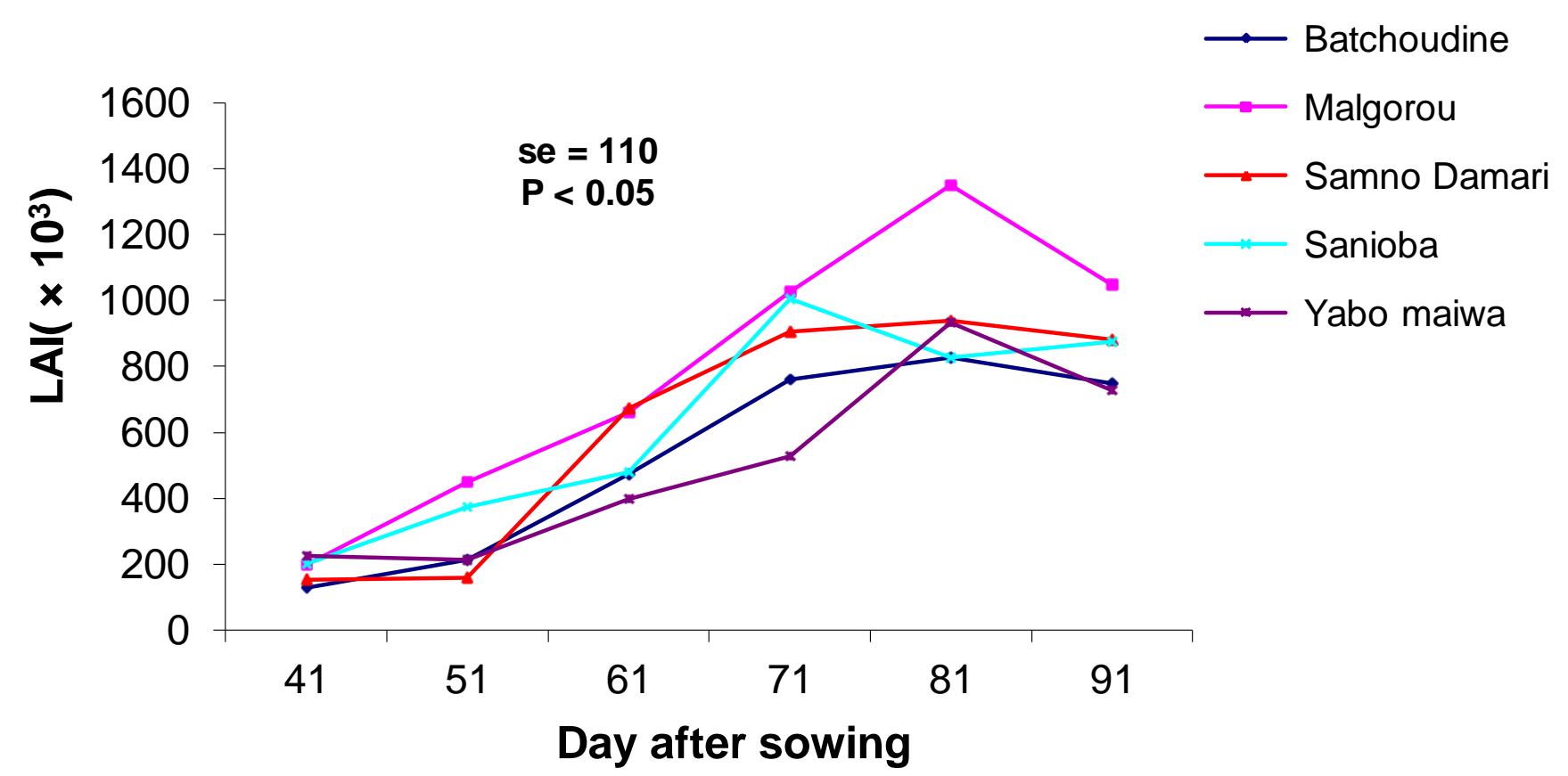

Figure 3. Leaf area index development of five pearl millet varieties during 91 days after sowing.

\section{Conclusion}

The experiment demonstrated that rainfed pearl millet can produce under about $500 \mathrm{~mm}$ annual rainfall high dry matter yields with reasonable forage quality, thus becoming a source of rainfed forage in semi-arid Sahel.
Longer duration varieties are most suitable for forage production because the long period of growth before seeds set allows them to produce more dry matter than the shorter duration varieties. The Malgorou variety produced more dry matter than the other four varieties. The reasons for the significantly higher dry matter 


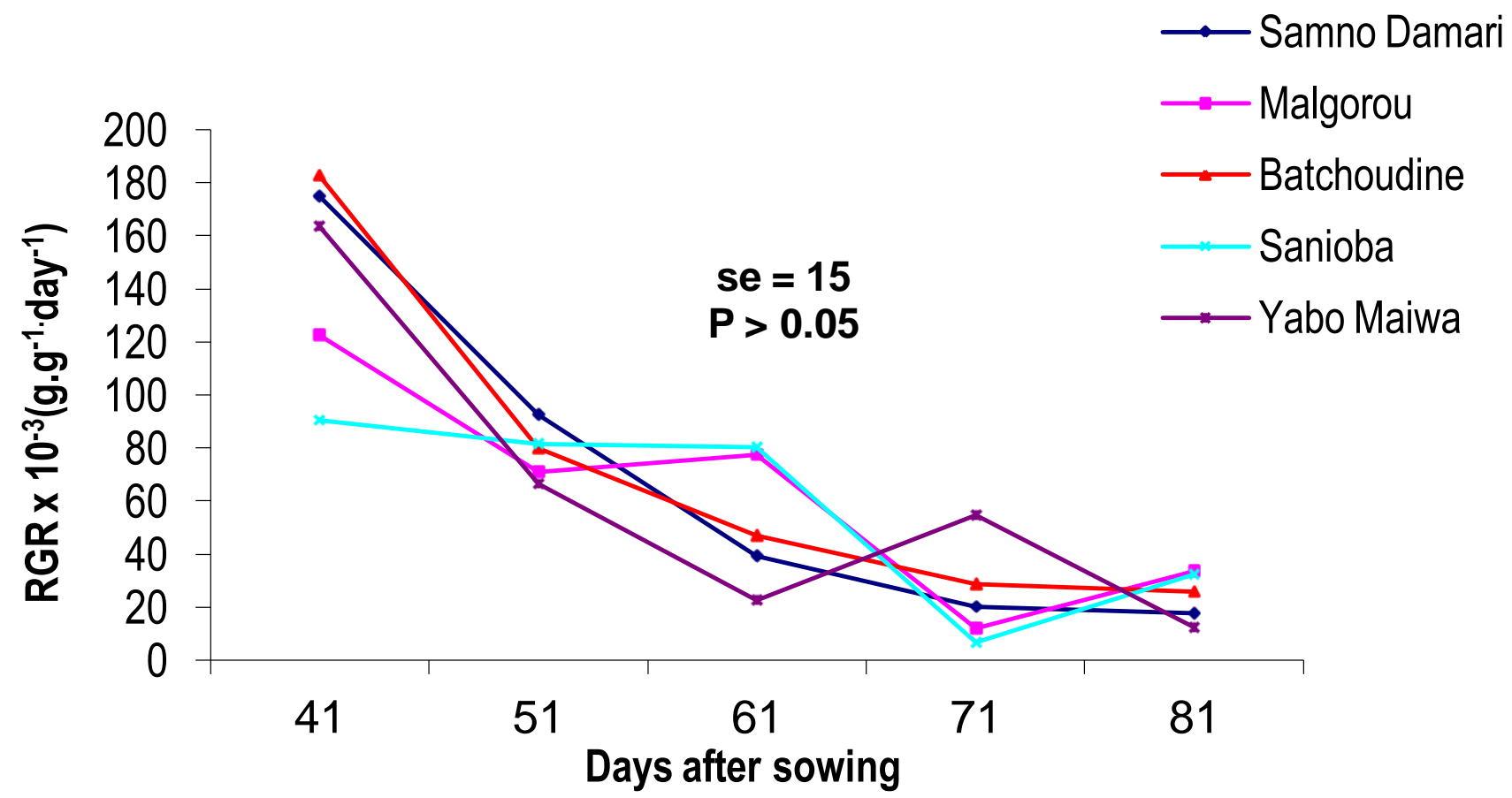

Figure 4. Relative Growth Rate of five pearl millet varieties during 81 days after sowing.

Table 3. Grain yield and yield components at grain harvesting.

\begin{tabular}{|c|c|c|c|c|}
\hline Variety & Density & Grains (kg/ha) & Dry leaves (kg/ha) & Dry stem (kg/ha) \\
\hline \multirow{2}{*}{ Batchoudine } & $1 \mathrm{~m} \times 0.5 \mathrm{~m}$ & 1,983 & 990 & 4,070 \\
\hline & $1 \mathrm{~m} \times 1 \mathrm{~m}$ & 1,887 & 819 & 3,222 \\
\hline \multirow{2}{*}{ Malgorou } & $1 \mathrm{~m} \times 0.5 \mathrm{~m}$ & 1,490 & 1,752 & 4,895 \\
\hline & $1 \mathrm{~m} \times 1 \mathrm{~m}$ & 1,170 & 1,238 & 3,688 \\
\hline \multirow{2}{*}{ Sanioba } & $1 \mathrm{~m} \times 0.5 \mathrm{~m}$ & 1,885 & 1,124 & 3,350 \\
\hline & $1 \mathrm{~m} \times 1 \mathrm{~m}$ & 1,526 & 810 & 2,517 \\
\hline \multirow{2}{*}{ Samno Damari } & $1 \mathrm{~m} \times 0.5 \mathrm{~m}$ & 2,188 & 1,067 & 4,252 \\
\hline & $1 \mathrm{~m} \times 1 \mathrm{~m}$ & 1,660 & 714 & 2,632 \\
\hline \multirow{2}{*}{ Yabo Maiwa } & $1 \mathrm{~m} \times 0.5 \mathrm{~m}$ & 1,632 & 1,048 & 3,529 \\
\hline & $1 \mathrm{~m} \times 1 \mathrm{~m}$ & 1,269 & 724 & 2,825 \\
\hline \multicolumn{5}{|l|}{ Probability } \\
\hline Variety & & $<0.001$ & $<0.001$ & 0.014 \\
\hline Planting Densities & & $<0.001$ & $<0.001$ & $<0.001$ \\
\hline
\end{tabular}

production of Malgorou were a longer period before reaching boot stage, allowing more leaf and stem production and production of a higher number of tillers. Malgorou also had the highest dry matter content at grain harvest, making it a candidate for a dual purpose (grain/forage) variety for the Sahel.

In addition, with a seasonal rainfall of $540 \mathrm{~mm}$ and short dry spells, a density of 20,000 plants/ha gives higher dry matter and grain yield than a density of 10,000 plants/ha. With the exception of Somno Damari, the 
Table 4. Means separation on Grain yield and yield components at grain harvesting.

\begin{tabular}{llccc}
\hline Data & Treatments & Grains (kg/ha) & Dry leaves (kg/ha) & Dry stem (kg/ha) \\
\hline & Batchoudine & $1,935^{\mathrm{a}}$ & $905^{\mathrm{b}}$ & $3,646^{\mathrm{ab}}$ \\
& Malgorou & $1,330^{\mathrm{b}}$ & $1,495^{\mathrm{a}}$ & $4,292^{\mathrm{a}}$ \\
Means of varieties & Sanioba & $1,706^{\mathrm{a}}$ & $967^{\mathrm{b}}$ & $2,934^{\mathrm{b}}$ \\
& Somno Damari & $1,924^{\mathrm{a}}$ & $891^{\mathrm{b}}$ & $3,442^{\mathrm{b}}$ \\
& Yabo Maiwa & $1,451^{\mathrm{b}}$ & $886^{\mathrm{b}}$ & $3,177^{\mathrm{b}}$ \\
& & & & $4,019^{\mathrm{a}}$ \\
Means of plant densities & $1 \mathrm{~m} \times 0.5 \mathrm{~m}$ & $1,832^{\mathrm{a}}$ & $1,196^{\mathrm{a}}$ & $2,977^{\mathrm{b}}$ \\
& $1 \mathrm{~m} \times 1 \mathrm{~m}$ & $1,502^{\mathrm{b}}$ & $861^{\mathrm{b}}$ & \\
LSD for: & & & 743 \\
Varieties & & & & 350 \\
Planting densities & & 263 & 186 & 113 \\
\hline
\end{tabular}

Table 5. Quality parameters of five pearl millet varieties planted at two planting densities harvested at three developmental stages.

\begin{tabular}{|c|c|c|c|c|c|c|}
\hline \multirow{2}{*}{ Cutting stage } & \multirow{2}{*}{ Variety } & \multirow{2}{*}{ Planting density } & Crude protein & In vitro OMD & Lignin & Cellulose \\
\hline & & & \multicolumn{4}{|c|}{$(\mathrm{g} / \mathrm{kg})$} \\
\hline \multirow{10}{*}{ Boot } & \multirow{2}{*}{ Batchoudine } & $1 \mathrm{~m} \times 0.5 \mathrm{~m}$ & 139.2 & 604.4 & 80.8 & 387.5 \\
\hline & & $1 \mathrm{~m} \times 1 \mathrm{~m}$ & 161.8 & 621.4 & 73.6 & 322.4 \\
\hline & \multirow{2}{*}{ Malgorou } & $1 \mathrm{~m} \times 0.5 \mathrm{~m}$ & 130.0 & 625.2 & 74.9 & 369.4 \\
\hline & & $1 \mathrm{~m} \times 1 \mathrm{~m}$ & 143.2 & 616.0 & 78.3 & 370.1 \\
\hline & \multirow{2}{*}{ Sanioba } & $1 \mathrm{~m} \times 0.5 \mathrm{~m}$ & 154.6 & 640.8 & 60.6 & 411.3 \\
\hline & & $1 \mathrm{~m} \times 1 \mathrm{~m}$ & 152.7 & 621.8 & 78.2 & 377 \\
\hline & Somno & $1 \mathrm{~m} \times 0.5 \mathrm{~m}$ & 143.2 & 633.5 & 76.4 & 379.3 \\
\hline & Damari & $1 \mathrm{~m} \times 1 \mathrm{~m}$ & 168.4 & 614.9 & 73.9 & 389.7 \\
\hline & \multirow[t]{2}{*}{ Yabo Maiwa } & $1 \mathrm{~m} \times 0.5 \mathrm{~m}$ & 120.8 & 620.7 & 69.7 & 400.9 \\
\hline & & $1 \mathrm{~m} \times 1 \mathrm{~m}$ & 149.1 & 624.8 & 79.0 & 413.1 \\
\hline \multirow{12}{*}{ Anthesis } & \multirow{2}{*}{ Batchoudine } & $1 \mathrm{~m} \times 0.5 \mathrm{~m}$ & 74.6 & 559.4 & 97.7 & 469.6 \\
\hline & & $1 \mathrm{~m} \times 1 \mathrm{~m}$ & 82.3 & 501.9 & 105.4 & 459.2 \\
\hline & \multirow{2}{*}{ Malgorou } & $1 \mathrm{~m} \times 0.5 \mathrm{~m}$ & 67.9 & 506.6 & 92.7 & 440.9 \\
\hline & & $1 \mathrm{~m} \times 1 \mathrm{~m}$ & 70.0 & 510.0 & 99.3 & 440.6 \\
\hline & \multirow{2}{*}{ Sanioba } & $1 \mathrm{~m} \times 0.5 \mathrm{~m}$ & 80.0 & 490.5 & 94.9 & 452.2 \\
\hline & & $1 \mathrm{~m} \times 1 \mathrm{~m}$ & 85.2 & 487.7 & 100.9 & 454.0 \\
\hline & Somno & $1 \mathrm{~m} \times 0.5 \mathrm{~m}$ & 74.6 & 511.7 & 103.6 & 463.3 \\
\hline & Damari & $1 \mathrm{~m} \times 1 \mathrm{~m}$ & 79.8 & 519.2 & 121.1 & 441.5 \\
\hline & \multirow[t]{2}{*}{ Yabo Maiwa } & $1 \mathrm{~m} \times 0.5 \mathrm{~m}$ & 74.6 & 488.6 & 119.2 & 448.7 \\
\hline & & $1 \mathrm{~m} \times 1 \mathrm{~m}$ & 73.4 & 501.4 & 107.8 & 482.1 \\
\hline & \multirow{2}{*}{ Batchoudine } & $1 \mathrm{~m} \times 0.5 \mathrm{~m}$ & 54.3 & 576.0 & 75.8 & 409.2 \\
\hline & & $1 \mathrm{~m} \times 1 \mathrm{~m}$ & 50.3 & 582.5 & 89.8 & 396.2 \\
\hline
\end{tabular}


Table 5. Contd.

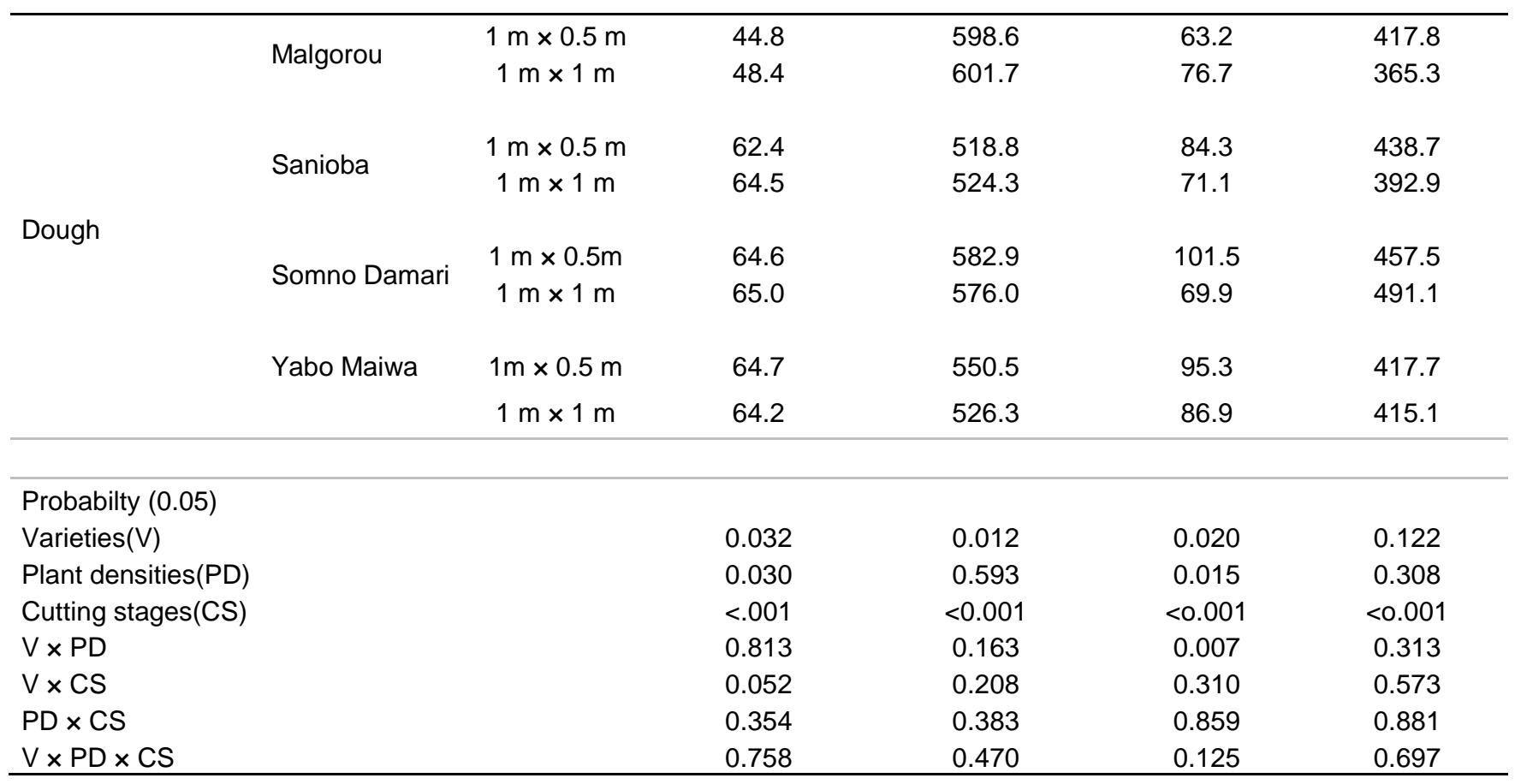

Table 6. Means separation on forage quality parameters of five pearl millet varieties planted at different planting densities.

\begin{tabular}{|c|c|c|c|c|c|}
\hline \multirow{2}{*}{ Data } & \multirow{2}{*}{ Treatment } & Crude protein & In vitro OMD & Lignin & Cellulose \\
\hline & & \multicolumn{4}{|c|}{$(\mathrm{g} / \mathrm{kg})$} \\
\hline \multirow{5}{*}{ Means of varieties } & Batchoudine & $93.8^{\mathrm{ab}}$ & $574.3^{a}$ & $87.2^{a b}$ & $407.6^{a}$ \\
\hline & Malgorou & $84.1^{b}$ & $576.4^{a}$ & $80.9^{b}$ & $400.7^{\mathrm{a}}$ \\
\hline & Sanioba & $99.9^{\mathrm{a}}$ & $547.3^{b}$ & $81.7^{\mathrm{b}}$ & $421.1^{\mathrm{a}}$ \\
\hline & Somno Damari & $99.3^{a}$ & $573.1^{a}$ & $91.1^{\mathrm{a}}$ & $437.1^{a}$ \\
\hline & Yabo Maiwa & $91.1^{\mathrm{ab}}$ & $552.1^{b}$ & $92.9^{\mathrm{a}}$ & $429.6^{a}$ \\
\hline \multirow{2}{*}{ Means of plant densities } & $1 \mathrm{~m} \times 0.5 \mathrm{~m}$ & $90.1^{b}$ & $567.2^{a}$ & $86.1^{a}$ & $424.3^{a}$ \\
\hline & $1 \mathrm{~m} \times 1 \mathrm{~m}$ & $97.2^{\mathrm{a}}$ & $561.9^{\mathrm{a}}$ & $87.5^{\mathrm{a}}$ & $414.1^{\mathrm{a}}$ \\
\hline \multirow{3}{*}{ Means of cutting stages } & Boot & $146.3^{\mathrm{a}}$ & $622.4^{\mathrm{a}}$ & $74.5^{\mathrm{b}}$ & $382.1^{\mathrm{b}}$ \\
\hline & Anthesis & $76.2^{\mathrm{b}}$ & $507.7^{\mathrm{C}}$ & $104.3^{a}$ & $455.2^{\mathrm{a}}$ \\
\hline & Dough & $58.3^{b}$ & $563.8^{\mathrm{b}}$ & $81.6^{\mathrm{b}}$ & $420.2^{\mathrm{ab}}$ \\
\hline \multicolumn{6}{|l|}{ LSD for: } \\
\hline Varieties & & 13.55 & 19.61 & 10.01 & 43.78 \\
\hline Plant densities & & 6.69 & 8.63 & 2.83 & 23.92 \\
\hline Cutting stages & & 28.68 & 29.03 & 7.53 & 46.10 \\
\hline
\end{tabular}

dough stage seems to be the most suitable for harvesting because at this stage the dry matter yield of most varieties is at its highest. However, organic matter digestibility and crude protein are higher at the boot stage compared with the dough stage.

\section{ACKNOWLEDGEMENTS}

The authors gratefully appreciate the technical assistance of the staff of Systems and Crops Diversification Program and of the International Livestock Research Institute 
(ILRI), at the International Crops Research Institute for semi-Arid Tropics (ICRISAT) Niamey, Niger.

\section{REFERENCES}

Agyemang K, Larbi A, Murty DS (1998). Evaluating variation in feed attributes of elite grain sorghum cultivars. Anim. Feed Sci. Technol. 72:189-197.

Alhassan WS, Nwasike CC (1987). Studies on the forage potential of some pearl millet (Pennisetum amaricanum [L.\} K.schum) cultivars. Yield and chemical composition at different ages. J. Anim. Prod. Res. 7:75-86.

Ali EA (2010). Grain Yield and Nitrogen Use Efficiency and pearl Millet as affected by plant Density, Nitrogen rate and Splitting in sandy Soil. American-Eurasian. Agric. Environ. Sci. 7(3):327-335.

Al-Suhaiban NA (2011). Better Forage and grain Quality of Pearl Millet (Pennisetun glaucum) under Different irrigation Water supplies and Plant densities. World Appl. Sci. J. 15(8):1136-1143.

Andrew DJ, Kumar KA (1992). Pearl millet for food feed and forage. Adv. Agron. 48:89-139.

Bremner JM, Mulvaney CS (1982). Nitrogen - total. P. 595-624. In A. L. Page, (ed.) Methods of soil analysis. Part 2. $2^{\text {nd }}$ Edition. Agron. Monogr. 9. ASA and SSSA. Madison, WI.

Burger AW, Hittle CN (1967). Yield, protein, nitrate and prussic acid content of sudan grass hybrids and pearl millets harvested at two cutting frequencies and two stubble heights. Agron. J. 59:250-262.

Burton GW, Primo AT, Lowery RS (1986). Effect of clipping frequency and maturity on the yield and quality of four pearl millets. Crop Sci. 12:187-188.

Craufurd PQ, Bidinger FR (1989). Potential and realized yield in pearl millet (Pennisetum americanum) as influenced by plant population density and live cycle duration. Field Crop Res. 22:211-225.

De Leeuw PN,Schildhorn TW (1978). Performance of young heifers on different dry season pastures. Ann.Rept. National Animal Production Research Institute, Shika-Zaria, Nigeria.

Glatzle A (1992). Feed resources in the Sahel. Anim. Res. Dev. 35:4358.

Hiernaux P, Ayantunde AA (2004). The Fakara: a semiarid agroecosystem under stress, Report of research activities of International Livestock Research Institute (ILRI) in Fakara, South-Western Niger, between 1994 and 2002 (Desert Margins Program, ICRISAT Niamey, Niger).
Hunt R (1990). Basic growth analysis. Plant growth analysis for beginners. Academic Press. London.

Johnson JC, Lowrey RS, Monswon WG, Burton GW (1968). Influence of the dwarf characteristic on composition and feeding value of near isogenic pearl millet. J. Dairy Sci. 51:1423-1427.

Makeri EE, Ugherughe PO (1992). Evaluation of the forage potentials of pearl millet in a semi arid tropic environment. Agron. Crop Sci. 169:319-329.

Menke KH, Roab L, Salewski A, Steingass H, Fritz D, Schneidel W (1979). The estimation of digestibility and metabolizable energy content of ruminant feeding stuffs from the gas production when they are incubated with rumen liquor. J. Agric. Sci. 93:217-222 Cambridge University.

Rajala KS (2006). The interaction between the length of dry spells and leaf area index on grain yield of pearl millet (Pennisetum glaucum). Master's thesis in Agroecology. Depart. Appl. Biol. Univers. Helsinki, Finland.

Reddy BVSP, Reddy PS, Bidinger F, Blümmel M (2003). Crop management factors influencing yield and quality of crop residues. Field Crops Research 84:57-77.

Sivakumar MVK (1987). Agroclimatic aspects of rainfed agriculture in the Sudano-Sahelian zone. In: Gaillard, T. \& Sadhana, V. 1989. Soil, Crop, and Water Management Systems for Rainfed Agriculture in the Sudano-Sahelian Zone: Proceedings of an International Workshop, ICRISAT Sahelian Centre, Niamey, Niger. pp. 17-38.

Stobbs TH (1975). A comparison of Zulu sorghum, bulrush millet and white panicum in terms of yield, forage quality, and milk production. Aust. J. Exp. Agric. Animal. Husb. 15:211-215.

Van Soest PJ, Robertson JB (1985). Analysis of forage and fibrous foods. A laboratory Manual for Science, 613. Cornell University, Ithaca, New York, USA.

West LT, Wilding LP, Landeck JK, Calhoun FG (1984). Soil survey of the ICRISAT Sahelian Centre, Niger, West Africa. Soil and Crop Sciences Department/Trop Soils, The Texas A\&M University System College Station, Texas and International Crops Research Institute for the Semi-Arid Tropics p. 66.

Williams TO, Fernàndez-Rivera S, Kelley TG (1997). The influence of socio-economic factors on the availability and utilization of crop residues as animal feeds. In: C. Renard (ed.), Crop Residues in Sustainable Mixed Crop/Livestock Farming Systems, (CAB International, Wallingford), 25-39. 